Jurnal Qua Teknika, Vol. 8 No. 2 September 2018

p-ISSN: 2088-2424; e-ISSN: 2527-3892

Fakultas Teknik Universitas Islam Balitar, Blitar

Http://qua.unisbablitar.ejournal.web.id; Email; quateknika@Gmail.com

Mustofa ihwanudin, Yanu Shalahuddin, Fajar Yumono. 2018. Simulasi Gangguan Voltage Sag dan

Voltage Swell Pada Jaringan 20 kv Menggunakan Matlab Simulink. Jurnal Qua Teknika, (2018), 8(2) : 1-15

\title{
SIMULASI GANGGUAN VOLTAGE SAG DAN VOLTAGE SWELL PADA JARINGAN 20 KV MENGGUNAKAN MATLAB SIMULINK
}

\author{
Mustofa ihwanudin'), Yanu Shalahuddin, Fajar Yumono. \\ Fakultas Teknik, Universitas Islam Kadiri \\ JL. Sersan Suharmadji No. 38 Kota Kediri Jawa Timur \\ 1email: musto.ihwan92@gmail.com
}

\begin{abstract}
ABSTRAK
Pada jaringan distribusi sering muncul gangguan yang bisa mengakibatkan penurunan kualitas daya, diatara penyebab penurunan kualitas daya adalah voltage sag dan voltage swell. Gangguan jenis ini dapat mengakibatkan gagal operasi peralatan terutama yang menggunakan komponen elektronik daya. Penelitian berupa simulasi untuk menggambarkan terjadinya voltage sag dan voltage swell yang disebabkan gangguan fasa ke tanah dan pelepasan beban yang di variasi dengan sambungan trafo distribusi yang berbeda. Simulasi dilakukan menggunakan software matlab simulink. Hasilnya model simulasi mampu menggambarkan sinyal voltage sag akibat hubung singkat satu fasa, dua fasa, tiga fasa ke tanah dan sinyal voltage swell akibat pelepasan beban.
\end{abstract}

Kata kunci : Kualitas daya, voltage sag,voltage swell, simulink

\section{PENDAHULUAN}

Di indonesia jaringan listrik terdiri dari jaringan transmisi dan jaringan distribusi, jaringan transmisi berteganggan $70 \mathrm{KV}, 150 \mathrm{KV}, 170 \mathrm{KV}$ (SUTT),500 KV (SUTET). Sedangkan jaringan distribusi bertegangan $20 \mathrm{KV}$ dengan dikenal saluran udara bertegangan menenggah (SUTM) dan jaringan bertegangan $220 \mathrm{~V}$ dikenal dengan saluran bertegangan rendah (SUTR).

Pada jaringan transmisi maupun distribusi sering muncul gangguan yang bisa mengakibatkan penurunan kualitas daya, diantaranya gangguan yang disebut voltage sag dan voltage swell. Gangguan jenis ini dapat mengakibatkan gagal operasi sistem peralatan yang menggunakan komponen elektronik daya seperti switching, motor drive maupun peralatan kendali lain. Tidak operasinya peralatan tersebut dapat menyebabkan kerugian secara ekonomi yang cukup besar, terutama pada konsumen industri maupun penyedia tenaga tersebut.

Penelitian ini berfokus pada pembuatan model simulasi gangguan voltage sag dan voltage swell pada jaringan distribusi $20 \mathrm{KV}$ dengan software simulasi matlab simulink. Harapan melakukan simulasi ini adalah mengambarkan kejadian gangguan voltage sag dan voltage swell

\section{Gangguan voltage sag}

Voltage sag atau yang dikenal juga dengan istilah tegangan kedip adalah penurunan tegangan rms sebesar 0,9 - 0,1 pu dari tegangan nominal dalam waktu 0,5 cycles frekuensi nominal (10ms) sampai dengan 1 menit [15]. Ada beberapa penyebab terjadinya voltage sag pada sistem tenaga listrik seperti hubung singkat antar phasa atau phasa ke tanah, starting motor-motor induksi berdaya besar. [3]

\section{Gangguan voltage swell}

Voltage Swell didefinisikan sebagai peningkatan tegangan rms mulai dari $110 \%$ - $180 \%$ dari tegangan nominal dalam jangka waktu 0,5 cycle sampai 1 (satu) menit.[15] ini diklasifikasikan sebagai fenomena variasi tegangan durasi pendek, yang merupakan salah satu kategori umum masalah kualitas daya. Penyebab dari voltage swell diantaranya energizing of capacitor banks, pemutusan beban tiba - tiba. [2]

\section{METODE PENELITIAN}

Dalam melakukan penelitian ini digunakan alat sebagai berikut: a) Computer desktop, b) OS. Windows 8, c) Matlab Simulink R2009A.

\section{Pemodelan}

Langkah langkah untuk melakukan simulasi adalah sebagai berikut:

1. Mengetahui semua jenis jenis ganggauan voltage sag dan swell pada jaringan distribusi $20 \mathrm{kv}$,

2. Membuat model simulasi jaringan distribusi $20 \mathrm{kv}$ menggunakan softwere matlab Simulink, 
Jurnal Qua Teknika, Vol. 8 No. 2 September 2018

p-ISSN: 2088-2424; e-ISSN: 2527-3892

Fakultas Teknik Universitas Islam Balitar, Blitar

Http://qua.unisbablitar.ejournal.web.id; Email; quateknika@Gmail.com

Mustofa ihwanudin, Yanu Shalahuddin, Fajar Yumono. 2018. Simulasi Gangguan Voltage Sag dan

Voltage Swell Pada Jaringan 20 kv Menggunakan Matlab Simulink. Jurnal Qua Teknika, (2018), 8(2) : 1-15

3. Membuat model gangguan voltage sag dan swell pada jaringan distribusi $20 \mathrm{kv}$,

4. Melakukan simulasi voltage sag disebabkan oleh gangguan fasa ke tanah dengan variasi trafomator,

5. Melakukan simulasi voltage swell disebabkan oleh pelepasan beban dengan variasi trafomator.

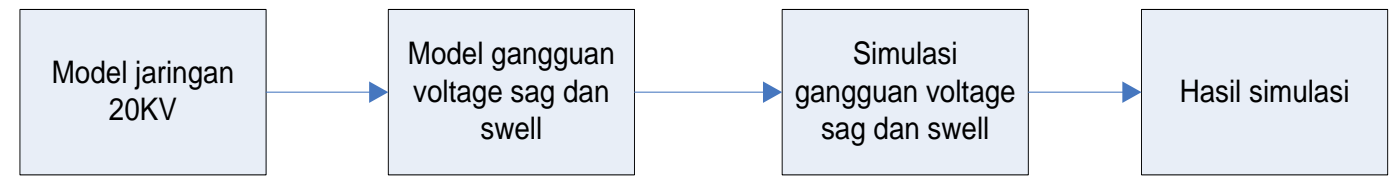

Gambar 1. Langkah pemodelan Simulasi Matlab-Simulink

Dari gambar 1 mengambarkan langkah langkah simulasi matlab simulink, dan pada tahap ini dibuat model gangguan voltage sag dan voltage swell yang bervariasi. Model simulasi dibuat untuk menggantikan keadaan pada jaringan $20 \mathrm{kv}$. Secara keseluruhan ada 8 variasi gangguan dengan perbedaan sambungan transformator distribusi dengan rincian sebagai berikut:

1) Satu fasa ke tanah dengan transformator sambungan $\vee g$ (bintang ground) $/ \mathrm{Vg}$.

2) Satu fasa ke tanah dengan transformator sambungan $\Delta$ (delta) $/ \mathrm{Vg}$.

3) Dua fasa ke tanah dengan transformator sambungan $\mathrm{rg} / \mathrm{Vg}$.

4) Dua fasa ke tanah dengan transformator sambungan $\Delta / \mathrm{Vg}$.

5) Dua fasa ke tanah dengan transformator sambungan $\Delta / \Delta$.

6) Tiga fasa ke tanah dengan transformator sambungan $\Delta / \mathrm{Vg}$.

7) Pelepasan beban dengan transformator sambungan $\mathrm{Yg} / \mathrm{Vg}$

8) Pelepasan beban dengan transformator sambungan $\Delta / \mathrm{Vg}$

Hasil pemodelan diharapkan dapat menggambarkan keadaan terjadinya gangguan pada jaringan $20 \mathrm{kv}$ dan akibat yang dapat ditimbulkan berupa voltage sag dan voltage swell pada saluran dimana terdapat beban sensitif yang harus dilindungi. Hasil simulasi berupa gambar scope dari matlab simulink akan menunjukkan dua aspek yaitu: besarnya penurunan tegangan rms bentuk gelombang dan durasi waktu terjadinya penurunan tegangan.

Langkah selanjutnya membuat simulasi jaringan $20 \mathrm{kv}$ dengan tahap - tahap sebagai berikut :

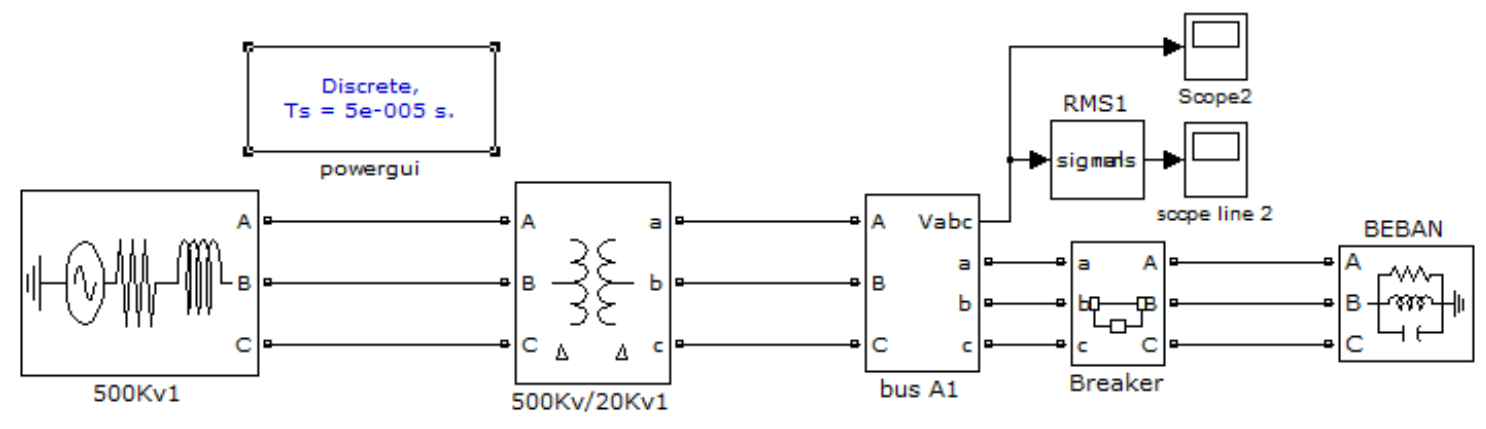

Gambar 2. Jaringan ditribusi $20 \mathrm{kv}$

Jaringan $20 \mathrm{kv}$ pada gambar 2 tanpa adanya gangguan jika disimulasikan pada bus akan menghasilkan sebuah sinyal seperti berikut 
Mustofa ihwanudin, Yanu Shalahuddin, Fajar Yumono. 2018. Simulasi Gangguan Voltage Sag dan Voltage Swell Pada Jaringan 20 kv Menggunakan Matlab Simulink. Jurnal Qua Teknika, (2018), 8(2) : 1-15

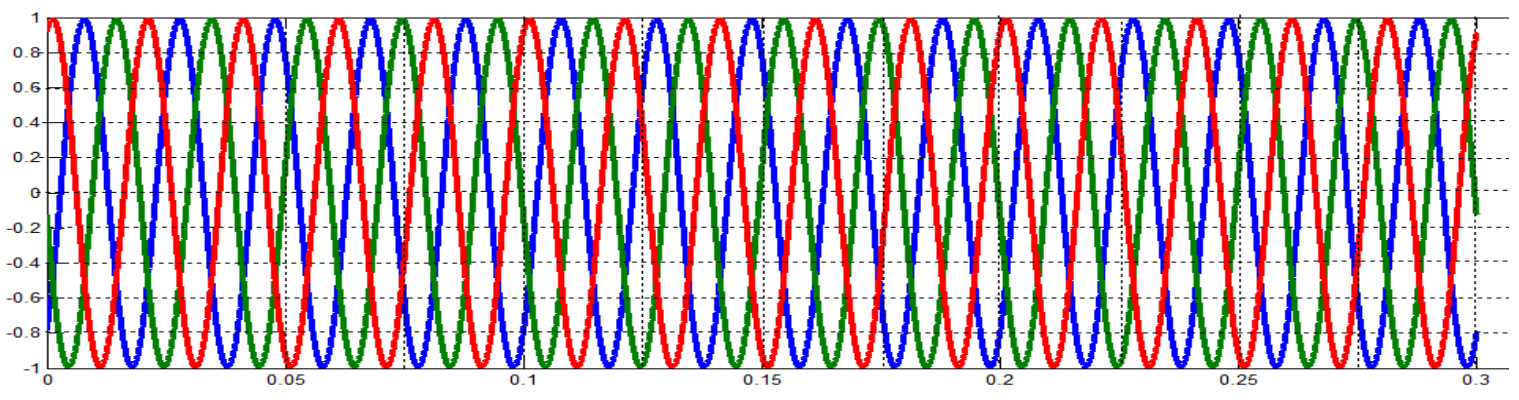

Gambar 3. Sinyal jaringan $20 \mathrm{kv}$

Setelah membuat jaringan distribusi 20kv yang terlihat pada gambar 2 dan disimulasikan, menghasilkan sebuah grafik yang terlihat pada gambar 3, langkah selanjutnya kita memberikan fault model yang terlihat gambar sebagai berikut.

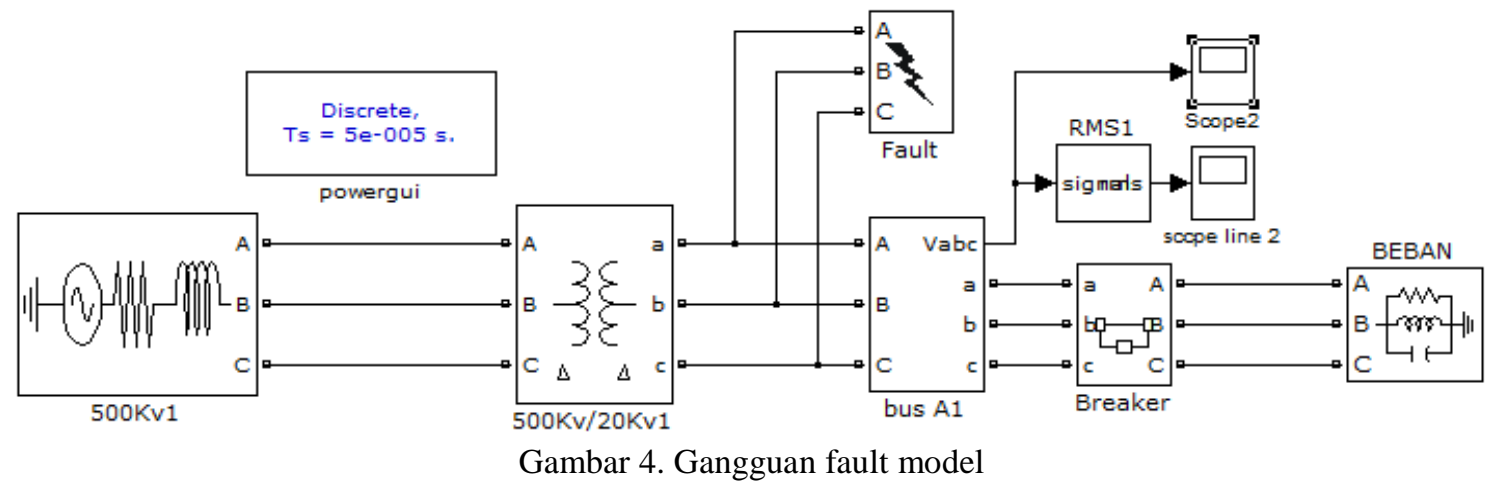

Model seperti gambar 4, jika disimulasikan menghasilkan grafik yang terlihat di gambar 5.

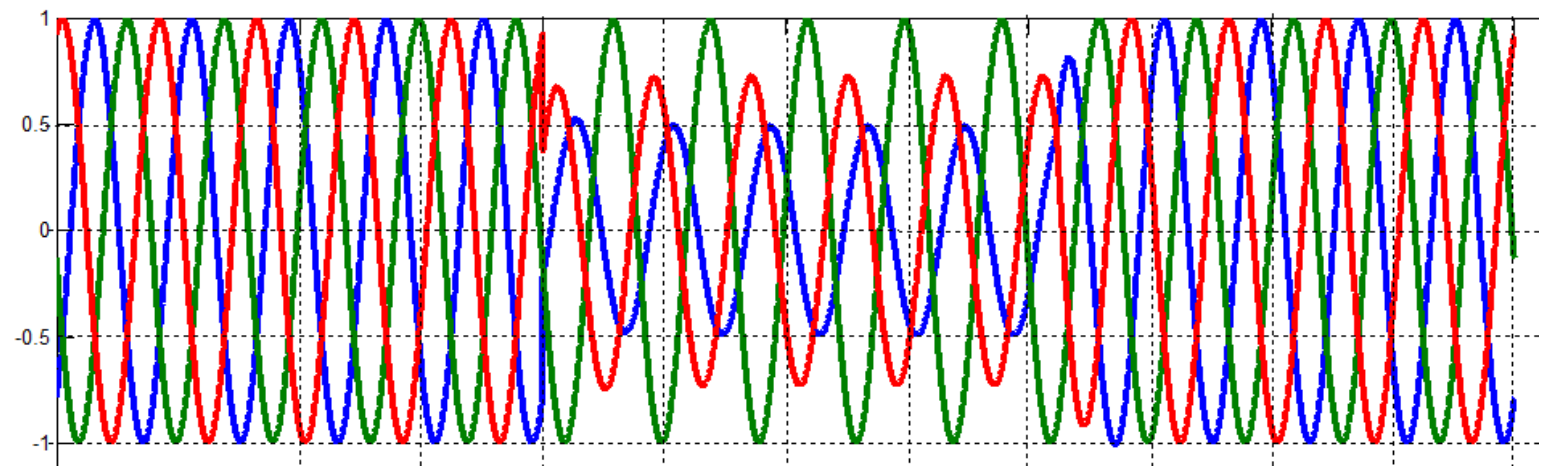

Gambar 5. Sinyal fault dua phasa ke tanah

\section{Model penelitian}

Model penelitian dibuat untuk menggambarkan jaringan dengan menggunakan 3 transformator distribusi (500kv ke 20kv) terdapat 3 bus A,B,C yang tersambung dengan beban. Model fault disambungkan pada bus A sedangkan pada bus $\mathrm{C}$ diberikan sirkuit breaker 3 fasa. 
Jurnal Qua Teknika, Vol. 8 No. 2 September 2018

p-ISSN: 2088-2424; e-ISSN: 2527-3892

Fakultas Teknik Universitas Islam Balitar, Blitar

Http://qua.unisbablitar.ejournal.web.id; Email; quateknika@Gmail.com

Mustofa ihwanudin, Yanu Shalahuddin, Fajar Yumono. 2018. Simulasi Gangguan Voltage Sag dan Voltage Swell Pada Jaringan 20 kv Menggunakan Matlab Simulink. Jurnal Qua Teknika, (2018), 8(2) : 1-15

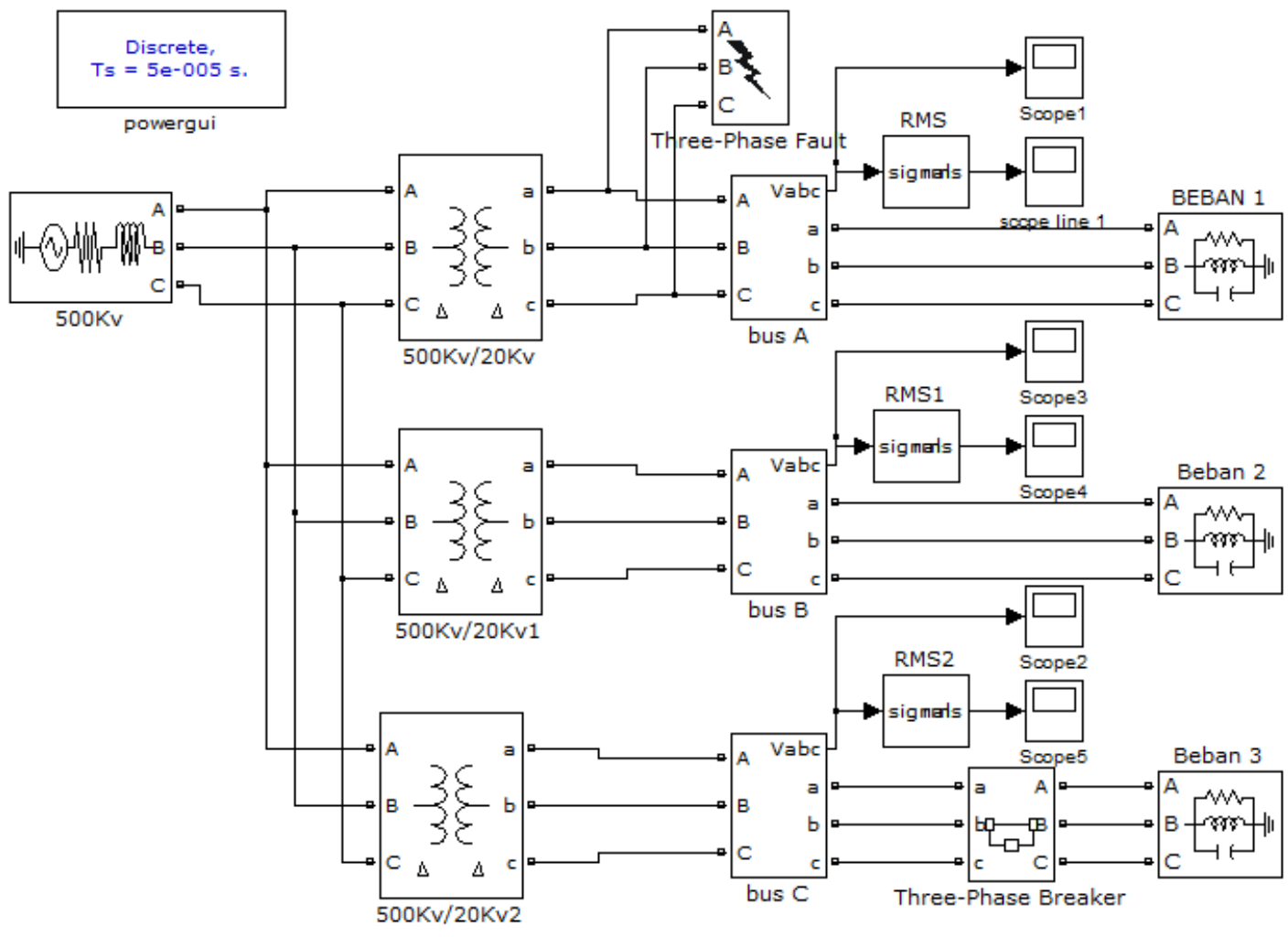

Gambar 6. Model penelitian

Model penelitian menggunakan parameter-parameter seperti ditunjukkan dalam tabel berikut.

Tabel 1. Parameter model penelitian

\begin{tabular}{|c|c|c|}
\hline Parameter Sistem & Parameter elemen system & Nilai elemen sistem \\
\hline \multirow{4}{*}{ Vs } & Vrms ph-ph & $500 \mathrm{Kv}$ \\
\hline & Frekuensi & $50 \mathrm{~Hz}$ \\
\hline & $\begin{array}{l}3 \text { phase short circuit level at base } \\
\text { voltage }\end{array}$ & $100 \mathrm{MVA}$ \\
\hline & $\mathrm{X} / \mathrm{R}$ ratio & 7 \\
\hline \multirow{4}{*}{ Fault /Gangguan } & Fault resistance Ron & $1 \mathrm{e}-3 \mathrm{Ohm}$ \\
\hline & Ground resistance $\mathrm{Rg}$ & $1 \mathrm{Ohm}$ \\
\hline & Transition times & {$[5 / 5010 / 50] \mathrm{s}$} \\
\hline & Snubber resistance $\mathrm{Rp}$ & $10000 \mathrm{Ohm}$ \\
\hline \multirow{3}{*}{3 fhasa Breaker } & Resistance Ron & $1 \mathrm{e}-3 \mathrm{Ohm}$ \\
\hline & Transition times & {$[0.30 .6] \mathrm{s}$} \\
\hline & Snubber resistance $\mathrm{Rp}$ & $10000 \mathrm{Ohm}$ \\
\hline \multirow{5}{*}{$\begin{array}{l}\text { Trafo phase } \\
500 \mathrm{kv} / 20 \mathrm{kv}\end{array}$} & Konfigurasi & Variasi \\
\hline & Nominal power and frequency & $1 \mathrm{MVA}, 50 \mathrm{~Hz}$ \\
\hline & Winding 1 (V1rms ph-ph, R1, L1) & $500 \mathrm{KV}, 2 \mathrm{e}-3,8 \mathrm{e}-2$ \\
\hline & Winding 2 (V2rms ph-ph, R2, L2) & $20 \mathrm{kv}, 2 \mathrm{e}-3,8 \mathrm{e}-2$ \\
\hline & $\mathrm{Rm} / \mathrm{Lm}$ & $500 / 500$ \\
\hline \multirow{2}{*}{ Bus $\mathrm{A}, \mathrm{B}$ dan $\mathrm{C}$} & Voltage measurement $(\mathrm{pu})$ & Phase to ground \\
\hline & Base Voltage Vrms ph-ph & $20 \mathrm{kV}$ \\
\hline Rms & Fundamental frequency & $50 \mathrm{~Hz}$ \\
\hline
\end{tabular}


Jurnal Qua Teknika, Vol. 8 No. 2 September 2018

p-ISSN: 2088-2424; e-ISSN: 2527-3892

Fakultas Teknik Universitas Islam Balitar, Blitar

Http://qua.unisbablitar.ejournal.web.id; Email; quateknika@Gmail.com

Mustofa ihwanudin, Yanu Shalahuddin, Fajar Yumono. 2018. Simulasi Gangguan Voltage Sag dan Voltage Swell Pada Jaringan 20 kv Menggunakan Matlab Simulink. Jurnal Qua Teknika, (2018), 8(2) : 1-15

\begin{tabular}{|l|l|c|}
\hline \multirow{4}{*}{ Beban } & Konfigurasi & Yg \\
\cline { 2 - 3 } & Nominal Vrms ph-ph & $380 \mathrm{~V}$ \\
\cline { 2 - 3 } & Frequency & $50 \mathrm{~Hz}$ \\
\cline { 2 - 3 } & Active power P & $28 \mathrm{MW}$ \\
\cline { 2 - 3 } & Reactive Power QL and Qc & 100 Var and 100 Var \\
\hline
\end{tabular}

Simulasi model penelitian

Tahapan ini akan dilakukan simulasi dan perhitungan besarnya voltage sag dan voltage swell saat terjadinya gangguan berdasarkan tipe yang telah disebut.

Langkah langkah penelitian

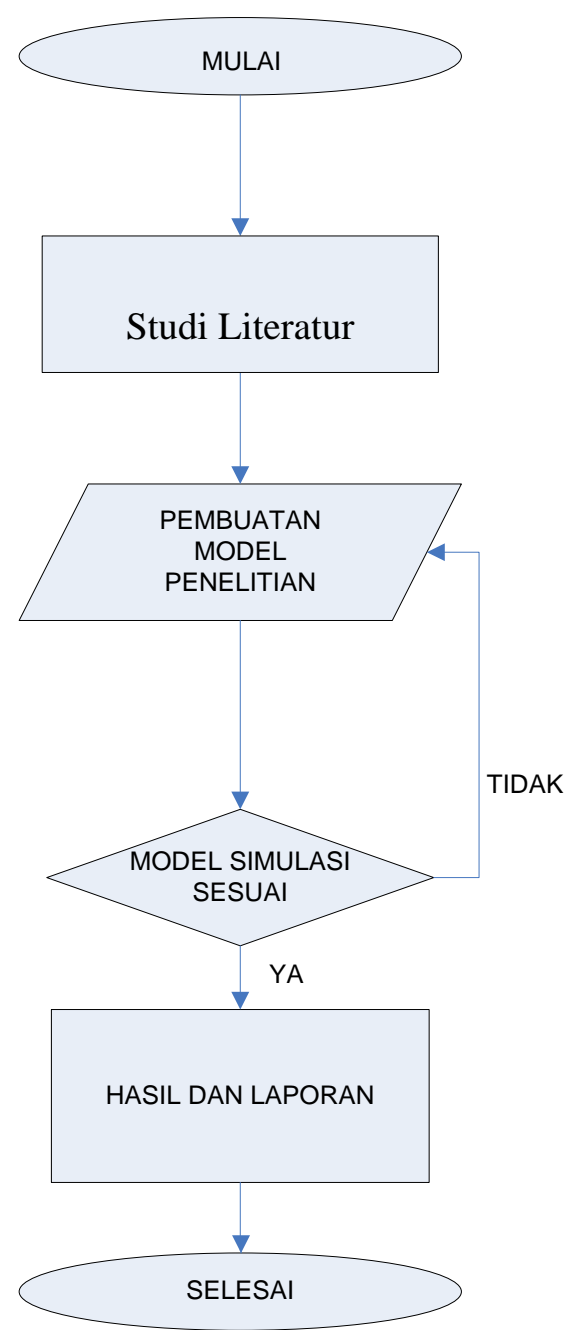

Gambar 7. Langkah - Langkah Penelitian

HASIL DAN PEMBAHASAN

Sinyal hasil Simulasi

Fault fasa ke tanah pada bus A

a) Satu fasa a sambungan transfomator $\mathrm{Yg} / \mathrm{Yg}$ : 
Jurnal Qua Teknika, Vol. 8 No. 2 September 2018

p-ISSN: 2088-2424; e-ISSN: 2527-3892

Fakultas Teknik Universitas Islam Balitar, Blitar

Http://qua.unisbablitar.ejournal.web.id; Email; quateknika@Gmail.com

Mustofa ihwanudin, Yanu Shalahuddin, Fajar Yumono. 2018. Simulasi Gangguan Voltage Sag dan Voltage Swell Pada Jaringan 20 kv Menggunakan Matlab Simulink.

Jurnal Qua Teknika, (2018), 8(2) : 1-15
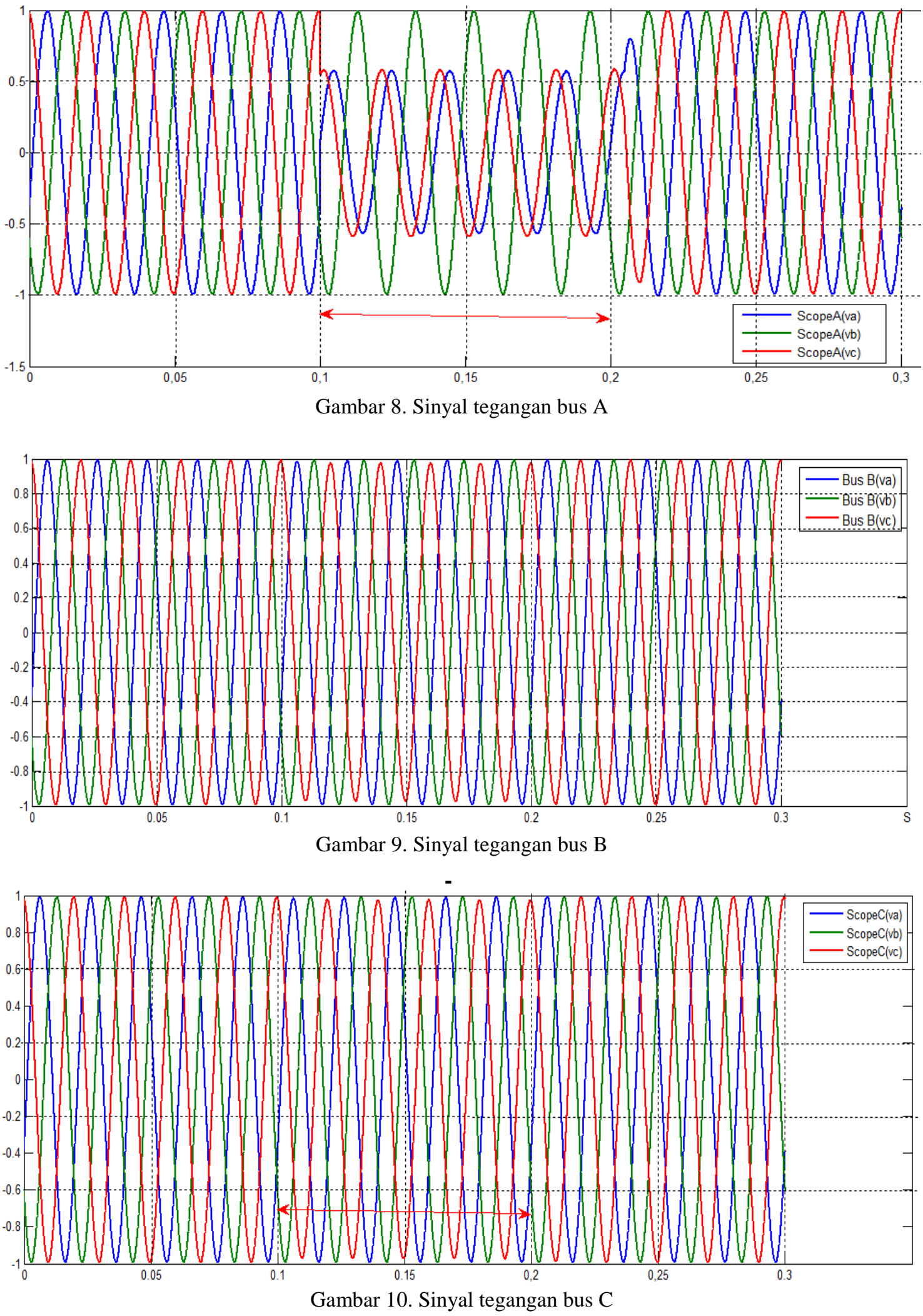
Jurnal Qua Teknika, Vol. 8 No. 2 September 2018

p-ISSN: 2088-2424; e-ISSN: 2527-3892

Fakultas Teknik Universitas Islam Balitar, Blitar

Http://qua.unisbablitar.ejournal.web.id; Email; quateknika@ Gmail.com

Mustofa ihwanudin, Yanu Shalahuddin, Fajar Yumono. 2018. Simulasi Gangguan Voltage Sag dan Voltage Swell Pada Jaringan 20 kv Menggunakan Matlab Simulink.

Jurnal Qua Teknika, (2018), 8(2): 1-15

Gambar diatas menunjukan bahwa pada bus A fasa a mengalami penurunan tegangan sebesar 0,43 pu, bus c mengalami penurunan sebesar 0,42 pu dengan durasi waktu $0,1 \mathrm{~s}$ sedangkan fasa $\mathrm{b}$ tidak mengalami penurunan.bus $\mathrm{B}$ dan bus $\mathrm{C}$ tidak menunjukkan adanya gangguan sinyal tegangan.

b) Satu fasa a sambungan transfomator $\Delta / \mathrm{Vg}$ :

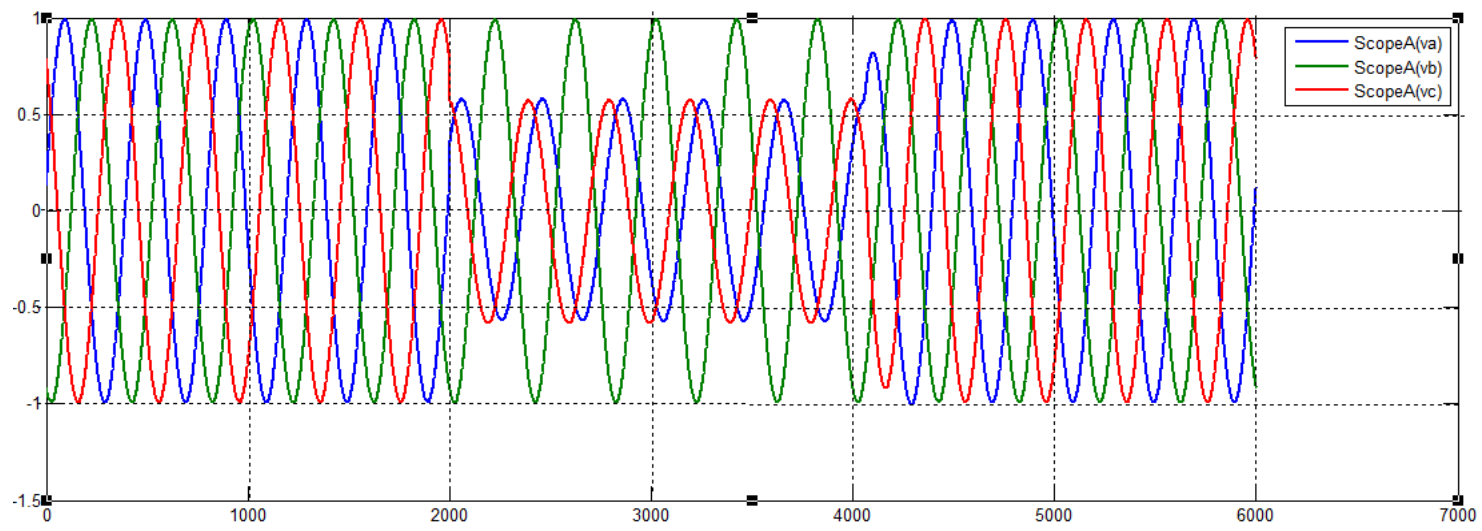

Gambar 11. Sinyal tegangan bus A

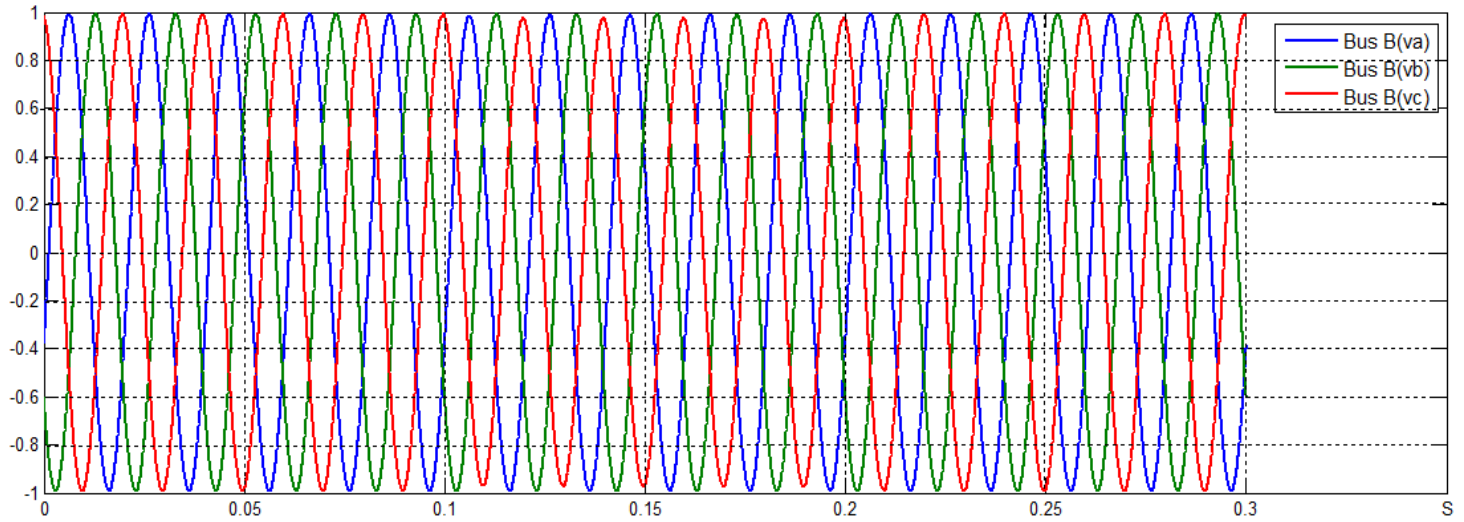

Gambar 12. Sinyal tegangan bus B

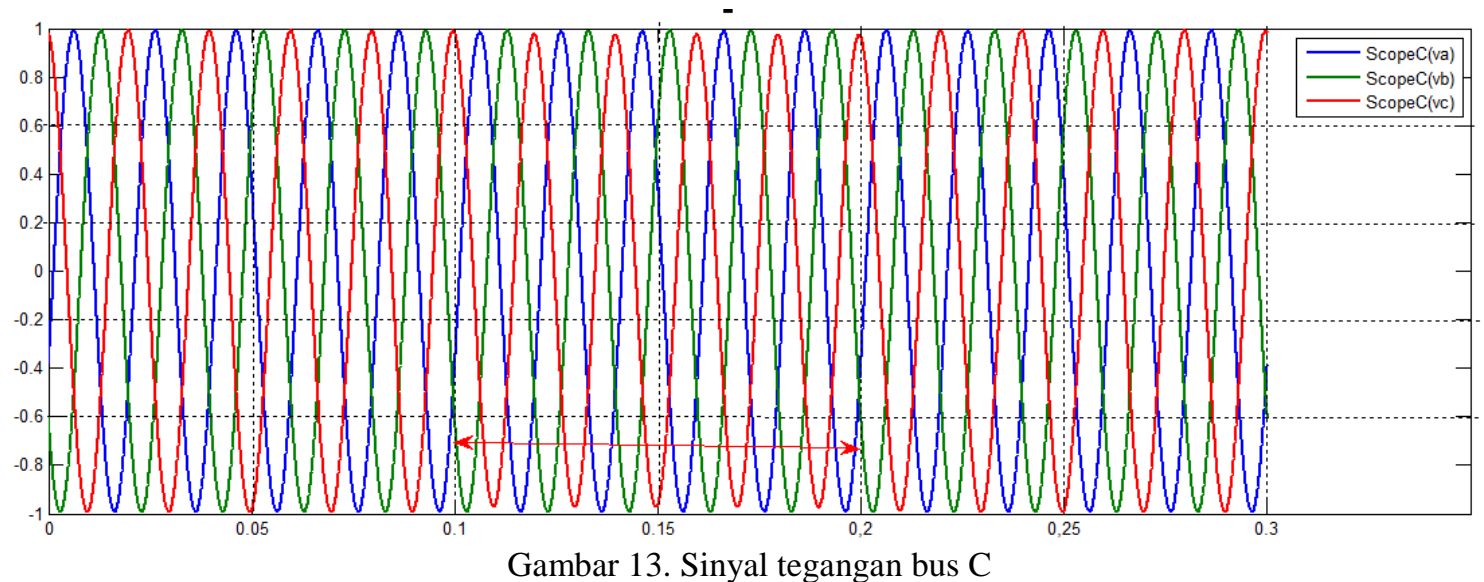


Jurnal Qua Teknika, Vol. 8 No. 2 September 2018

p-ISSN: 2088-2424; e-ISSN: 2527-3892

Fakultas Teknik Universitas Islam Balitar, Blitar

Http://qua.unisbablitar.ejournal.web.id; Email; quateknika@ Gmail.com

Mustofa ihwanudin, Yanu Shalahuddin, Fajar Yumono. 2018. Simulasi Gangguan Voltage Sag dan Voltage Swell Pada Jaringan 20 kv Menggunakan Matlab Simulink.

Jurnal Qua Teknika, (2018), 8(2): 1-15

Gambar diatas menunjukan bahwa pada bus A fasa a dan fasa c mengalami penurunan tegangan sebesar 0,42 pu dengan durasi waktu 0,1 s sedangkan fasa $\mathrm{b}$ tidak mengalami penurunan. Bus B dan bus $\mathrm{C}$ tidak menunjukkan adanya gangguan sinyal tegangan.

c) fasa a,b sambungan transfomator $\Delta / \mathrm{Vg}$ :

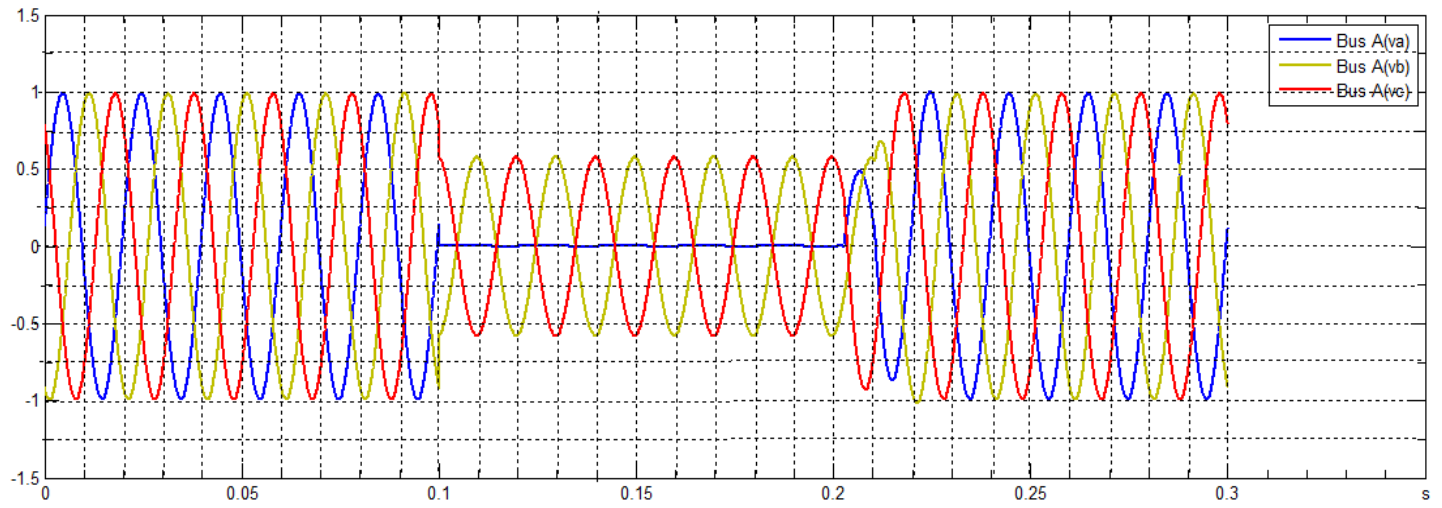

Gambar 14. Sinyal tegangan bus A

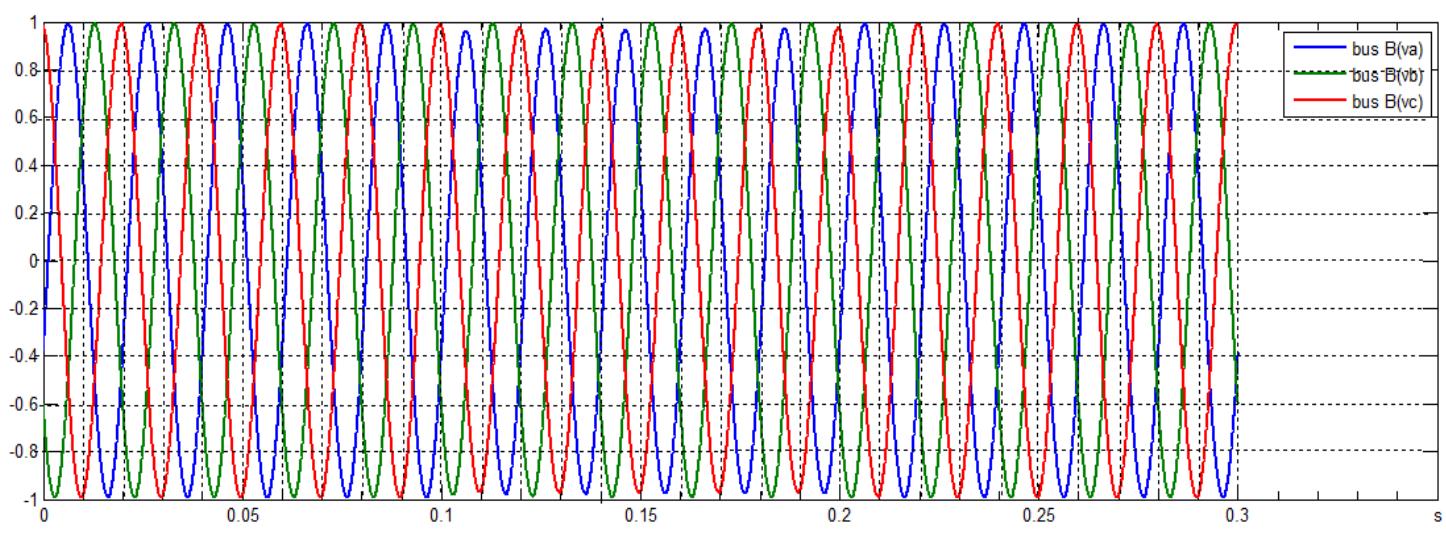

Gambar 15. Sinyal tegangan bus B

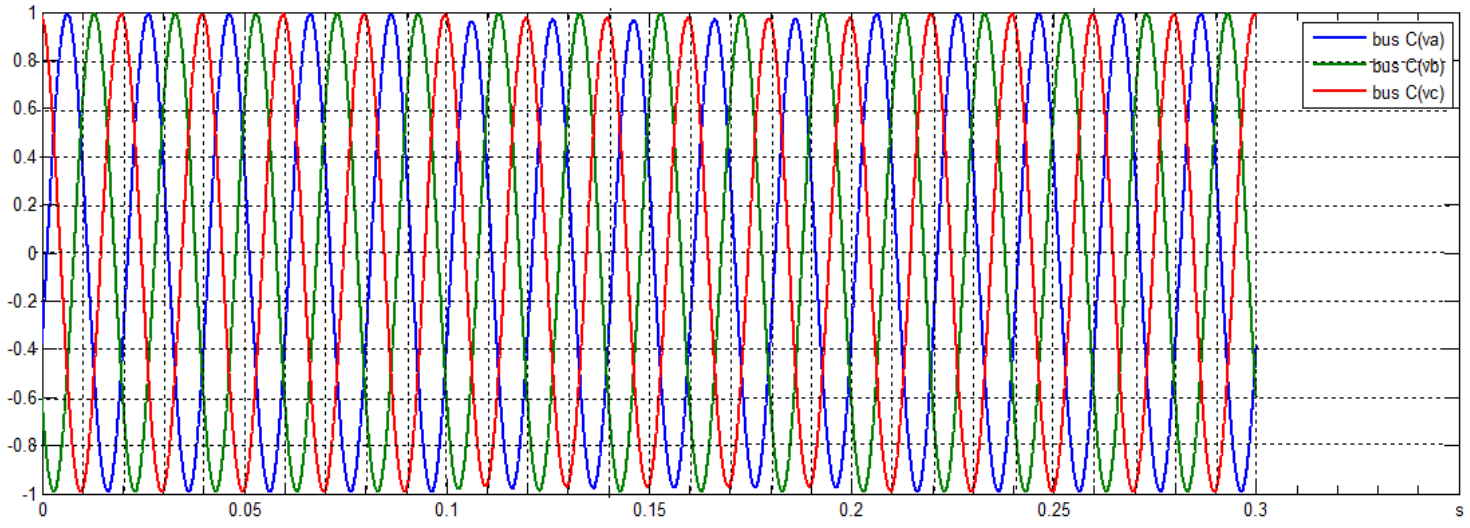

Gambar 16. Sinyal tegangan bus C 
Jurnal Qua Teknika, Vol. 8 No. 2 September 2018

p-ISSN: 2088-2424; e-ISSN: 2527-3892

Fakultas Teknik Universitas Islam Balitar, Blitar

Http://qua.unisbablitar.ejournal.web.id; Email; quateknika@ Gmail.com

Mustofa ihwanudin, Yanu Shalahuddin, Fajar Yumono. 2018. Simulasi Gangguan Voltage Sag dan Voltage Swell Pada Jaringan 20 kv Menggunakan Matlab Simulink.

Jurnal Qua Teknika, (2018), 8(2): 1-15

Gambar diatas menunjukan bahwa pada bus A fasa a mengalami penurunan sebesar 1pu sedangkan fasa b dan fasa c mengalami penurunan tegangan sebesar $0,42 \mathrm{pu}$, dengan durasi waktu $0,1 \mathrm{~s}$. Bus $\mathrm{B}$ dan bus $\mathrm{C}$ tidak menunjukkan adanya gangguan sinyal tegangan.

d) Fasa a,b sambungan transfomator $\Delta / \Delta$ :

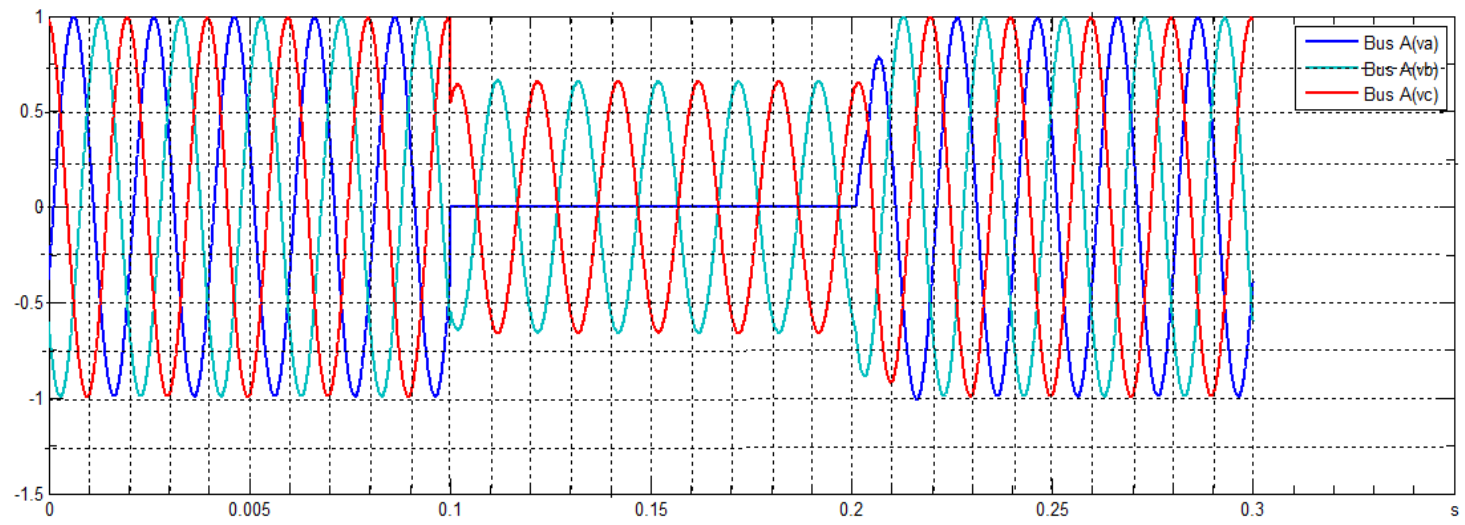

Gambar 17. Sinyal tegangan bus A

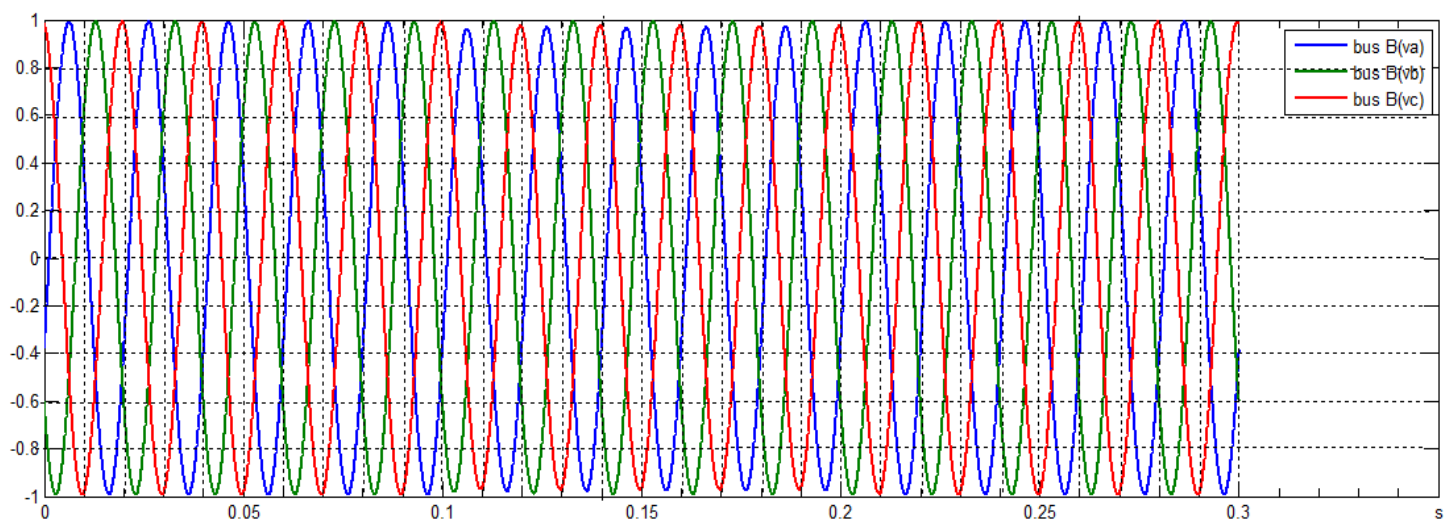

Gambar 18. Sinyal tegangan bus B

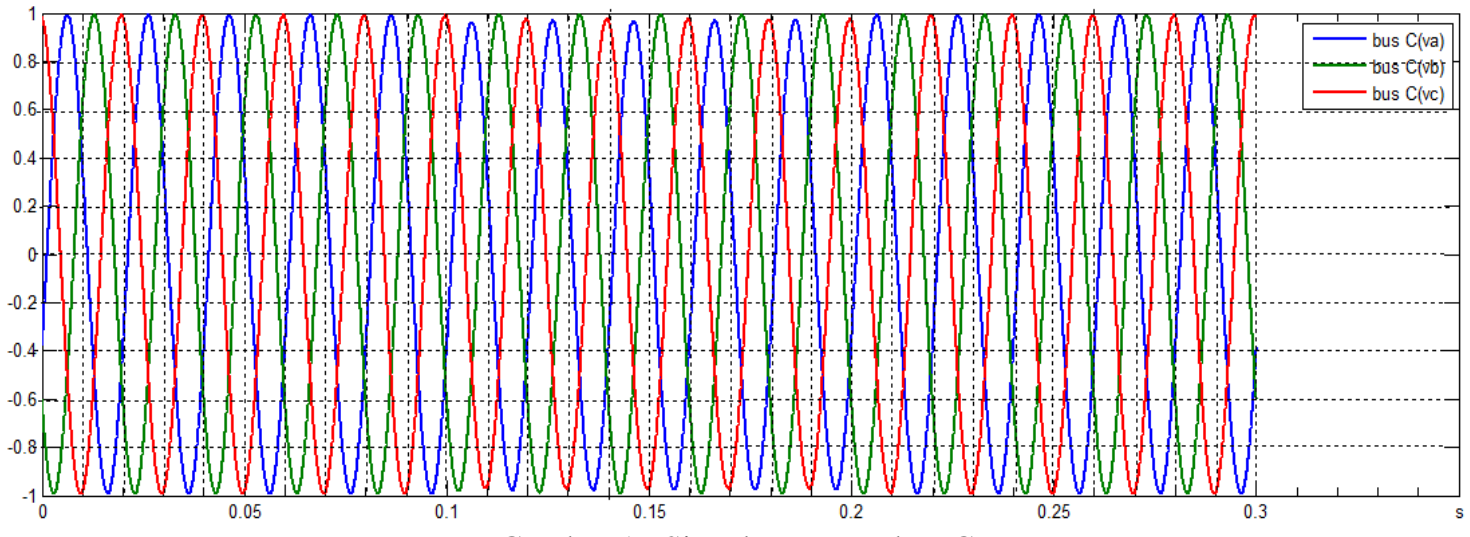

Gambar 19.Sinyal tegangan bus C 
Jurnal Qua Teknika, Vol. 8 No. 2 September 2018

p-ISSN: 2088-2424; e-ISSN: 2527-3892

Fakultas Teknik Universitas Islam Balitar, Blitar

Http://qua.unisbablitar.ejournal.web.id; Email; quateknika@ Gmail.com

Mustofa ihwanudin, Yanu Shalahuddin, Fajar Yumono. 2018. Simulasi Gangguan Voltage Sag dan Voltage Swell Pada Jaringan 20 kv Menggunakan Matlab Simulink.

Jurnal Qua Teknika, (2018), 8(2): 1-15

Gambar diatas menunjukan bahwa pada bus A fasa a mengalami penurunan sebesar 1pu sedangkan fasa b dan fasa c mengalami penurunan tegangan sebesar $0,36 \mathrm{pu}$, dengan durasi waktu $0,1 \mathrm{~s}$. Bus $\mathrm{B}$ dan bus $\mathrm{C}$ tidak menunjukkan adanya gangguan sinyal tegangan.

e) Fasa a,b sambungan transfomator $\mathrm{Yg} / \mathrm{Yg}$ :

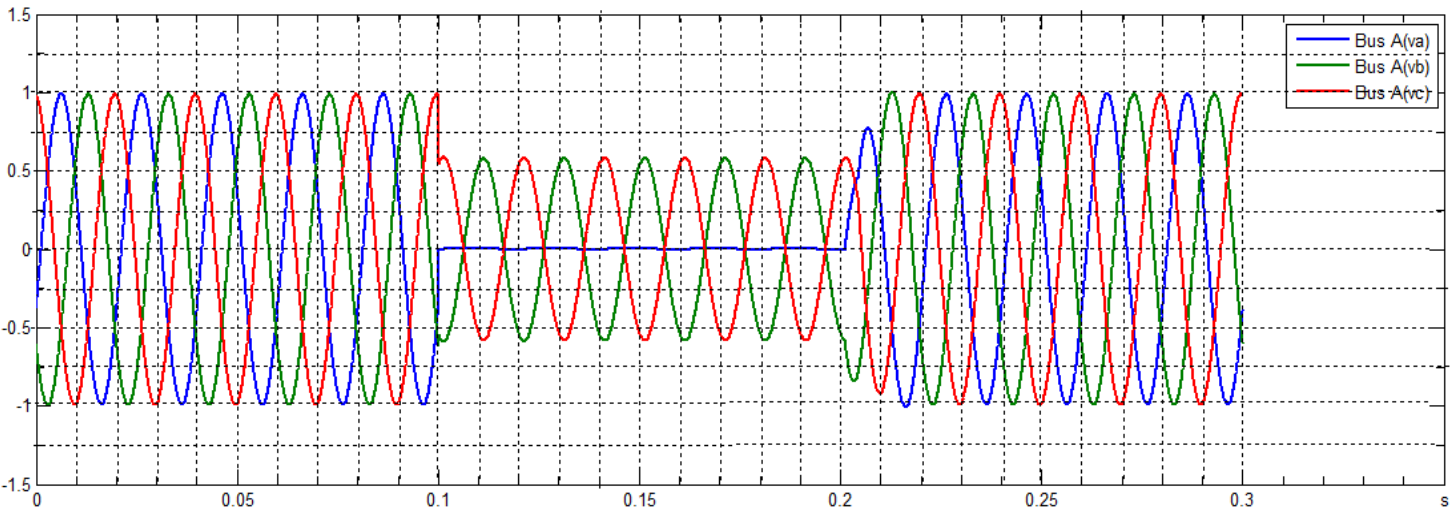

Gambar 20. Sinyal tegangan bus A

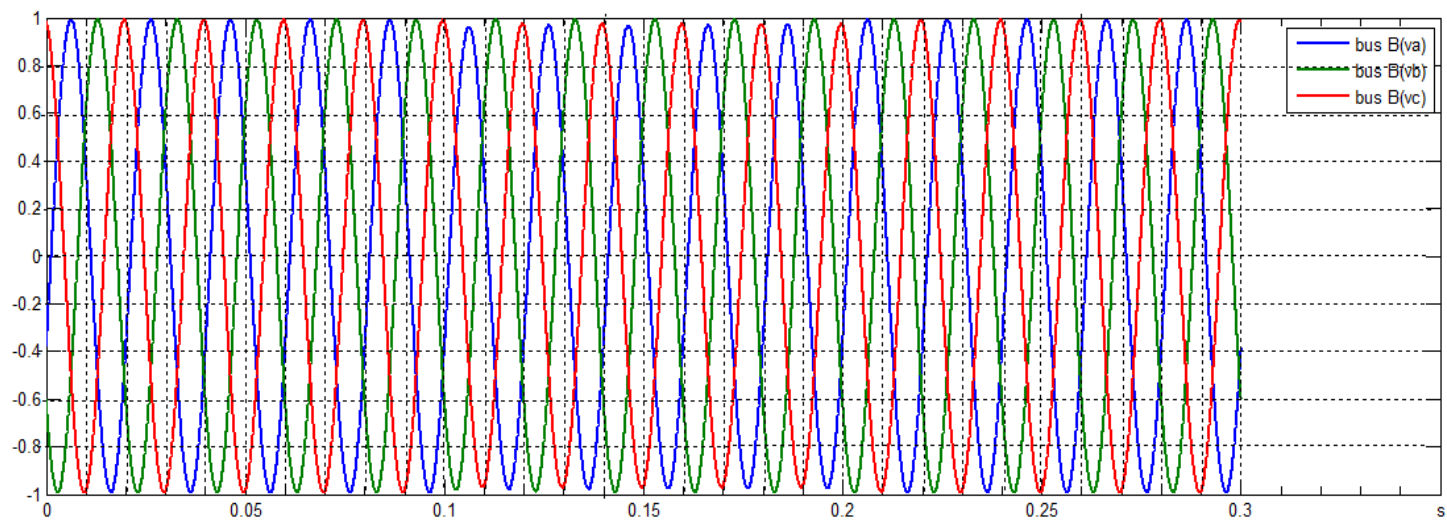

Gambar 21. Sinyal tegangan bus B

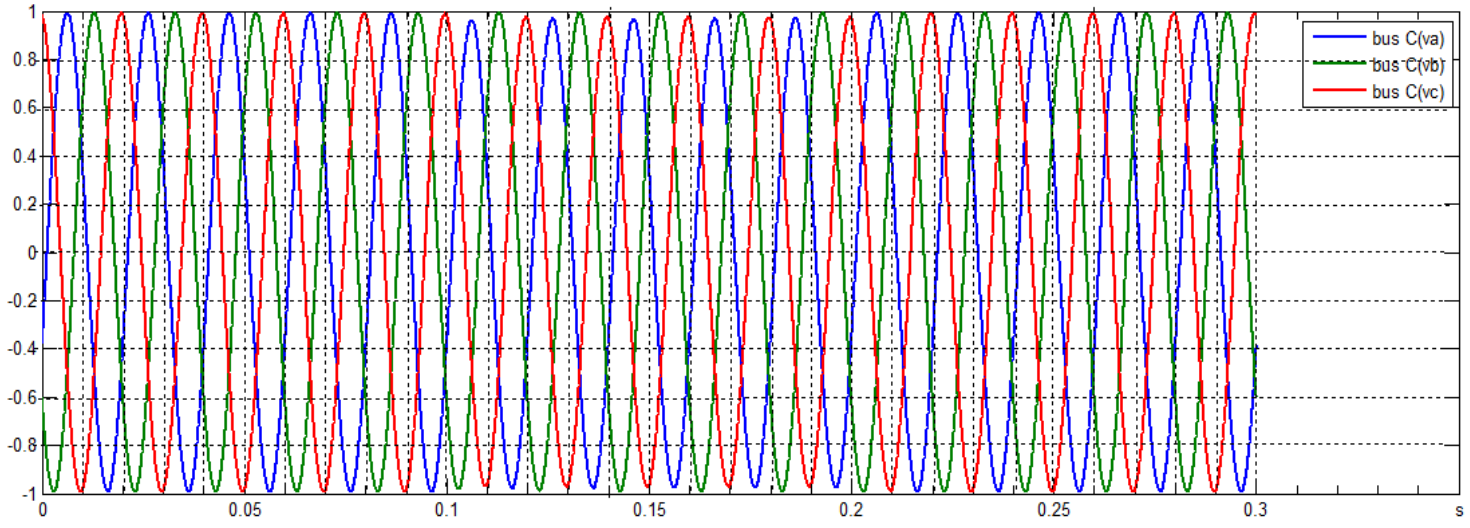

Gambar 22. Sinyal tegangan bus C 
Jurnal Qua Teknika, Vol. 8 No. 2 September 2018

p-ISSN: 2088-2424; e-ISSN: 2527-3892

Fakultas Teknik Universitas Islam Balitar, Blitar

Http://qua.unisbablitar.ejournal.web.id; Email; quateknika@ Gmail.com

Mustofa ihwanudin, Yanu Shalahuddin, Fajar Yumono. 2018. Simulasi Gangguan Voltage Sag dan Voltage Swell Pada Jaringan 20 kv Menggunakan Matlab Simulink.

Jurnal Qua Teknika, (2018), 8(2): 1-15

Gambar diatas menunjukan bahwa pada bus A fasa a mengalami penurunan sebesar 1pu sedangkan fasa b dan fasa c mengalami penurunan tegangan sebesar $0,42 \mathrm{pu}$, dengan durasi waktu $0,1 \mathrm{~s}$. Bus $\mathrm{B}$ dan bus $\mathrm{C}$ tidak menunjukkan adanya gangguan sinyal tegangan.

f) tiga fasa sambungan transfomator $\Delta / \mathrm{Vg}$ :
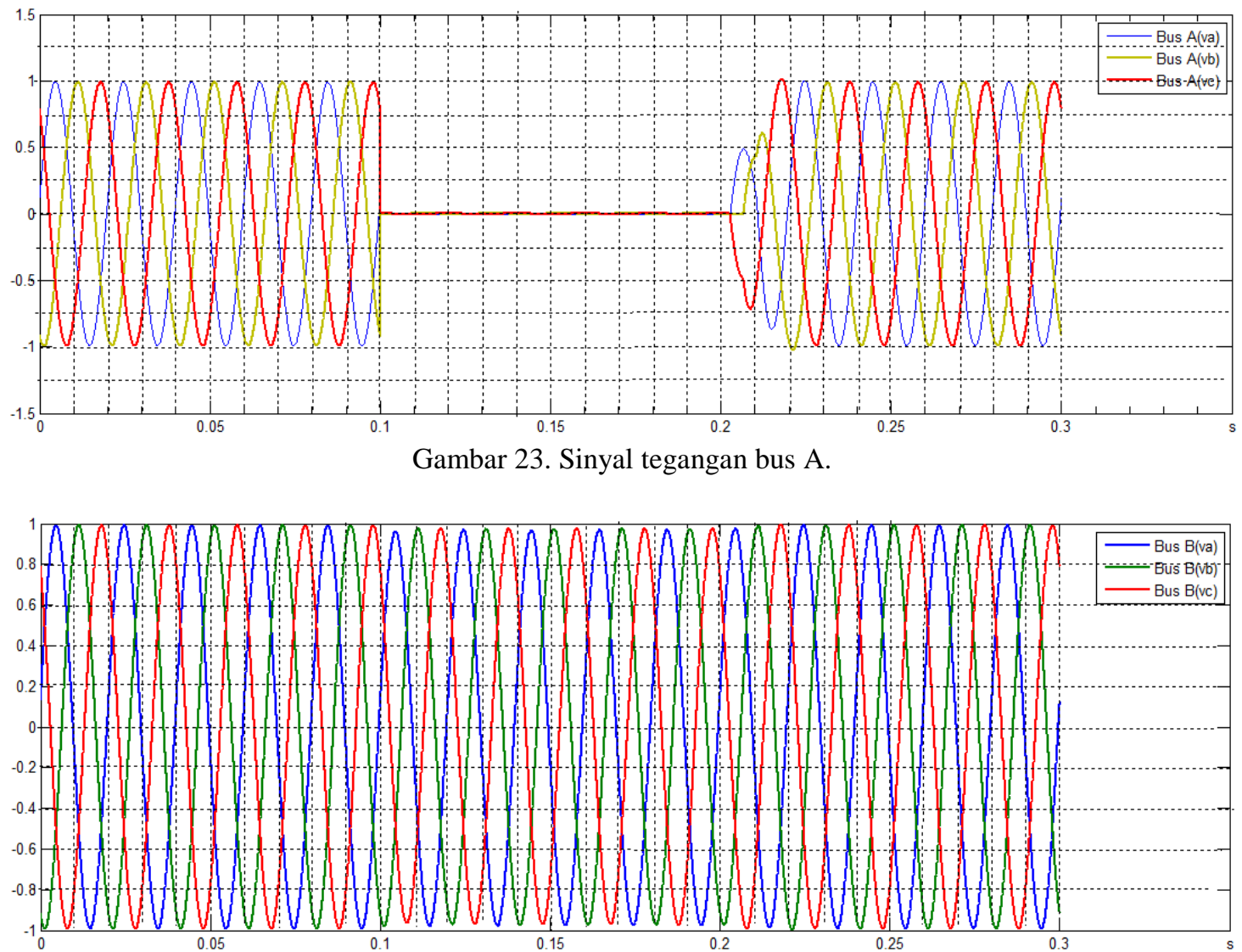

Gambar 24 Sinyal tegangan bus B.

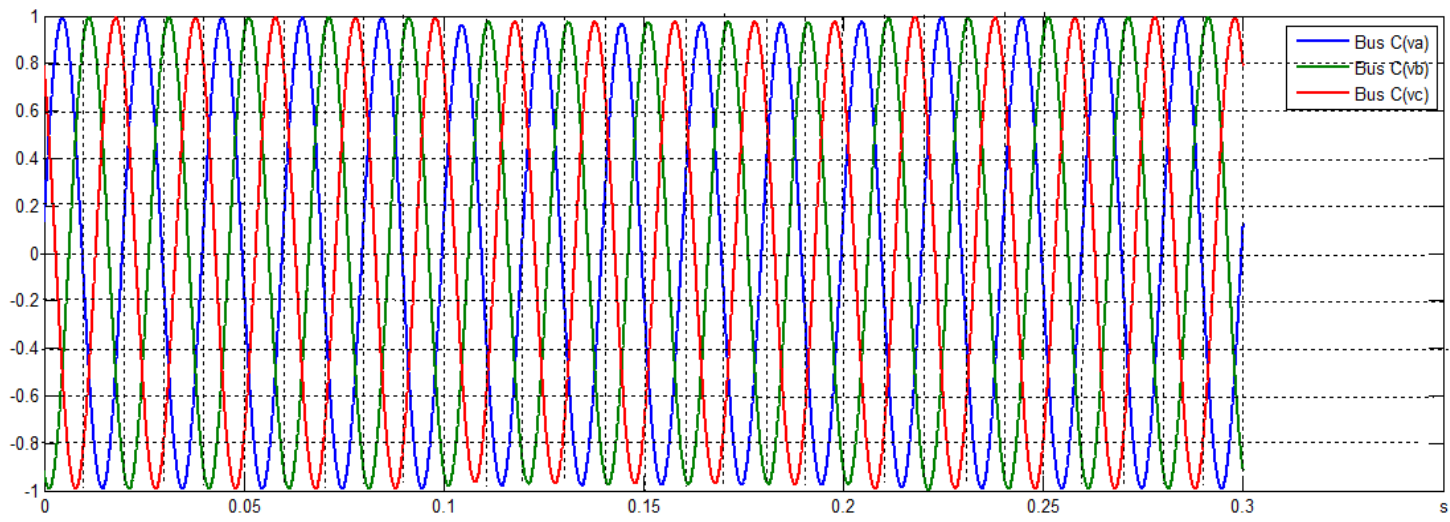

Gambar 25. Sinyal tegangan bus C

Gambar diatas menunjukan bahwa pada bus A pada ke tiga fasa mengalami penurunan sebesar 1pu dengan durasi waktu 0,1s. Bus B dan bus $\mathrm{C}$ tidak menunjukkan adanya gangguan sinyal tegangan. 
Jurnal Qua Teknika, Vol. 8 No. 2 September 2018

p-ISSN: 2088-2424; e-ISSN: 2527-3892

Fakultas Teknik Universitas Islam Balitar, Blitar

Http://qua.unisbablitar.ejournal.web.id; Email; quateknika@Gmail.com

Mustofa ihwanudin, Yanu Shalahuddin, Fajar Yumono. 2018. Simulasi Gangguan Voltage Sag dan Voltage Swell Pada Jaringan 20 kv Menggunakan Matlab Simulink.

Jurnal Qua Teknika, (2018), 8(2) : 1-15

Pelepasan beban pada bus C

a. Sambungan transfomator $\mathrm{Yg} / \mathrm{Yg}$ :

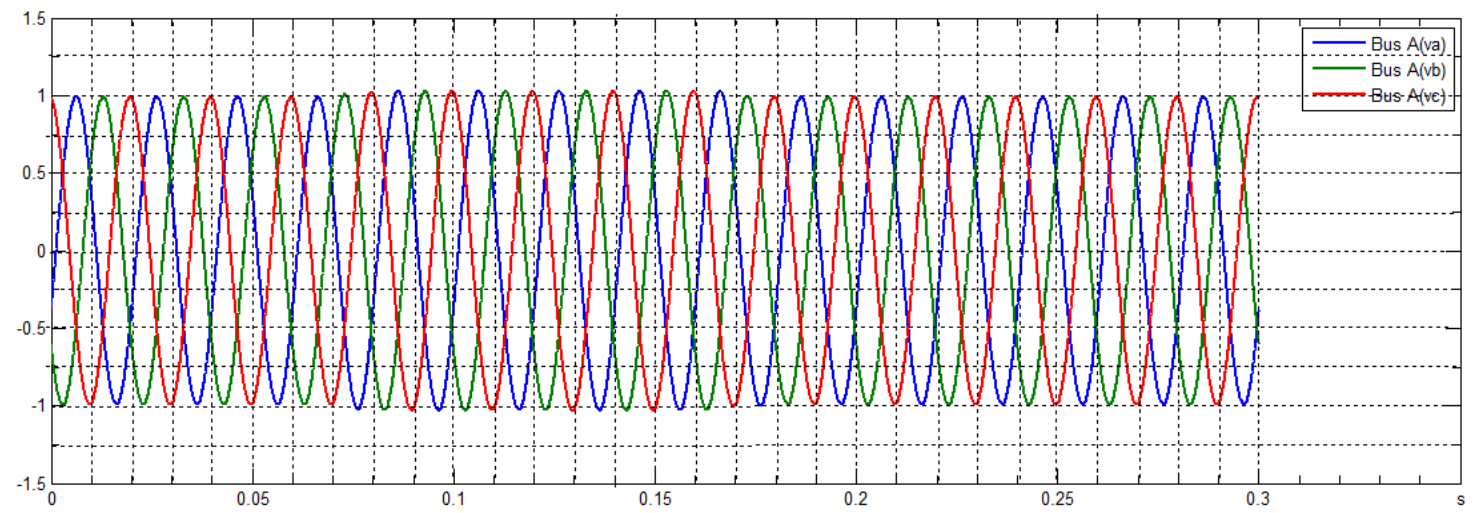

Gambar 26. Sinyal tegangan bus A
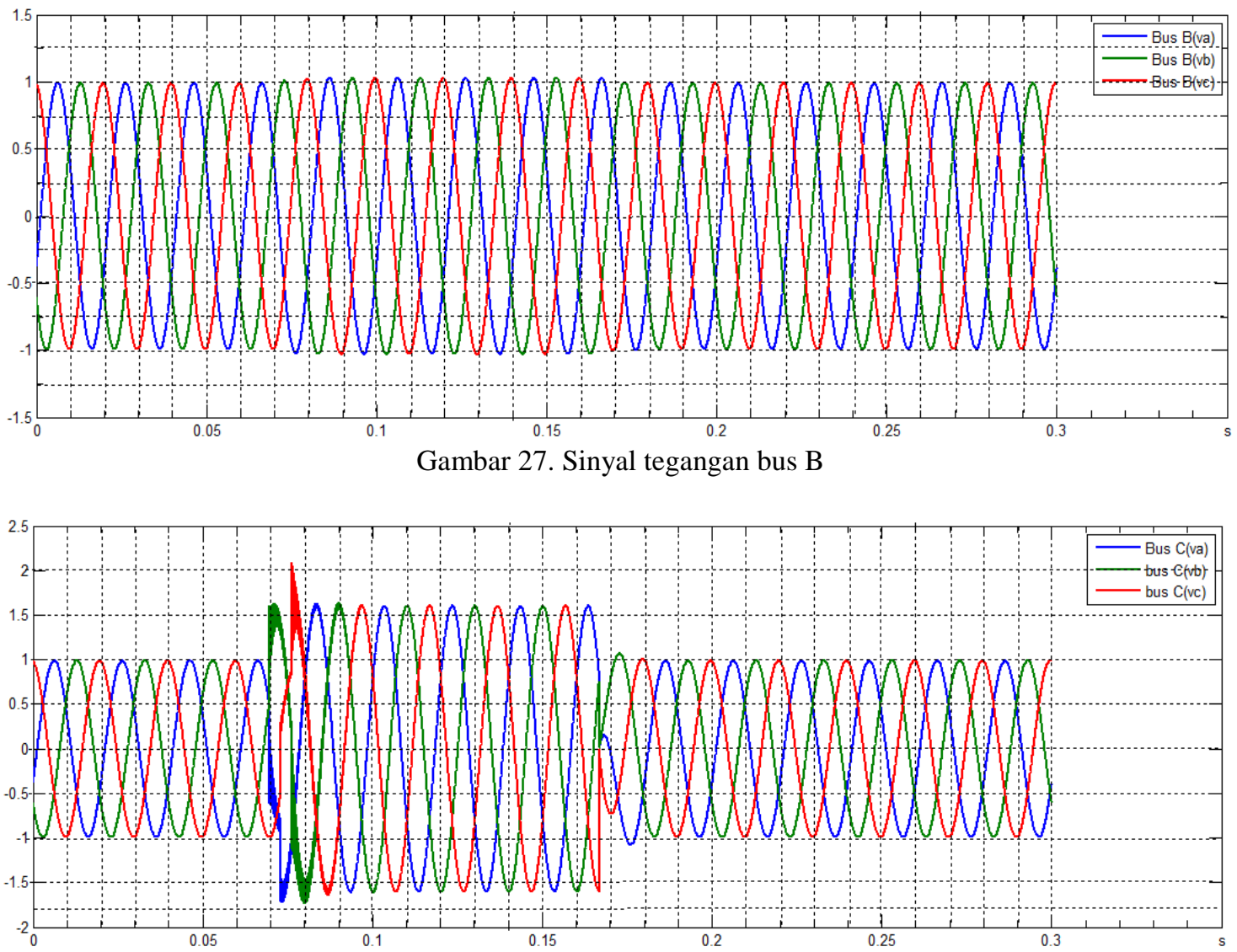

Gambar 28. Sinyal tegangan bus C

Gambar diatas menunjukan bahwa pada bus C pada ketiga fasa mengalami kenaikan sebesar 0.64pu dengan durasi waktu 0,1s. Bus A dan bus B tidak menunjukkan adanya gangguan sinyal tegangan.

b. $\quad$ sambungan transfomator $\Delta / \mathrm{Vg}$ : 
Jurnal Qua Teknika, Vol. 8 No. 2 September 2018

p-ISSN: 2088-2424; e-ISSN: 2527-3892

Fakultas Teknik Universitas Islam Balitar, Blitar

Http://qua.unisbablitar.ejournal.web.id; Email; quateknika@Gmail.com

Mustofa ihwanudin, Yanu Shalahuddin, Fajar Yumono. 2018. Simulasi Gangguan Voltage Sag dan Voltage Swell Pada Jaringan 20 kv Menggunakan Matlab Simulink.

Jurnal Qua Teknika, (2018), 8(2) : 1-15

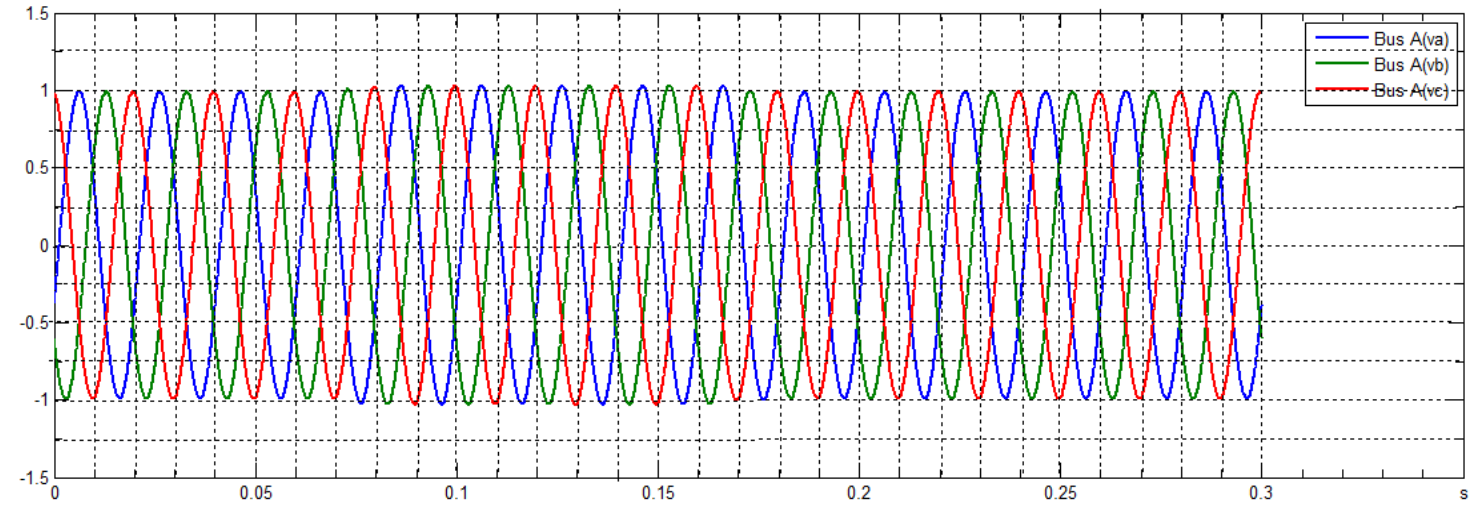

Gambar 29. Sinyal tegangan bus A.

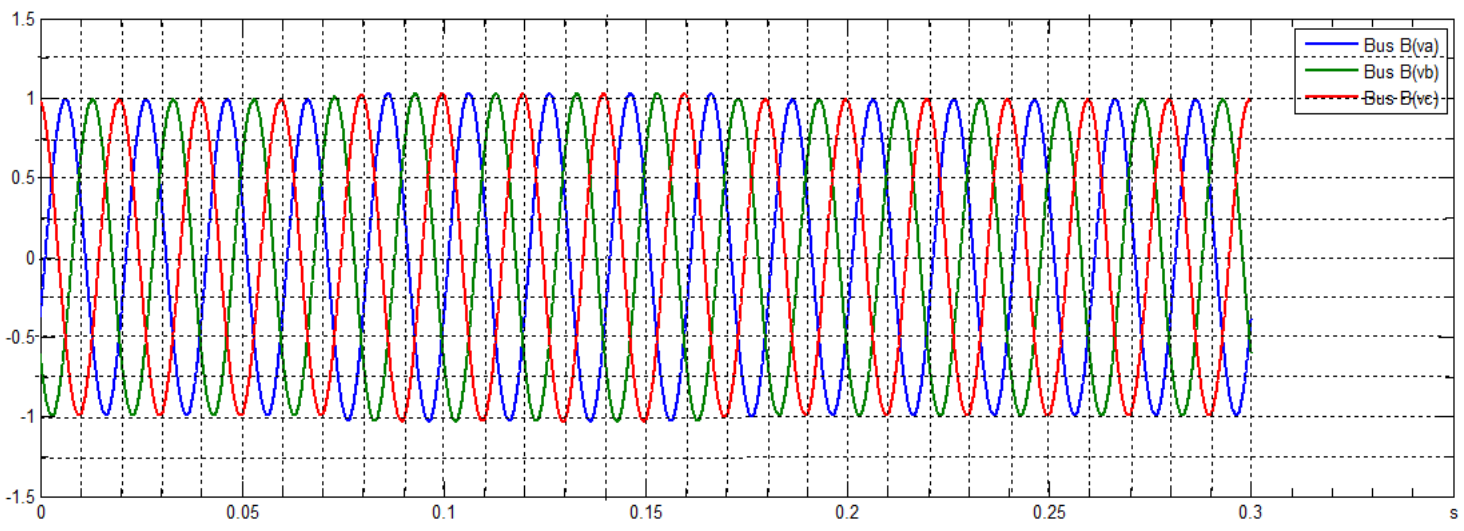

Gambar 30. Sinyal tegangan bus B

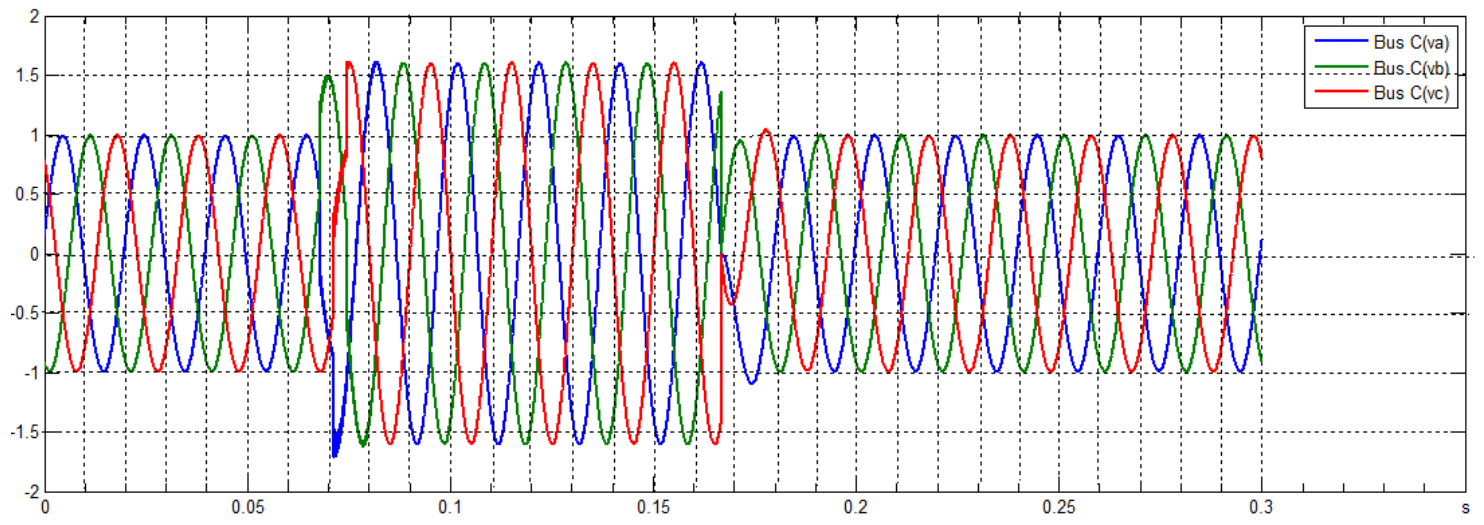

Gambar 31. Sinyal tegangan bus C

Gambar diatas menunjukan bahwa pada bus C pada ketiga fasa mengalami kenaikan sebesar 0.62pu dengan durasi waktu 0,1s. Bus A dan bus B tidak menunjukkan adanya gangguan sinyal tegangan.

\section{Hasil simulasi}

Berdasarkan simulasi yang telah dilakukan dari 8 tipe uji berupa gangguan hubung singkat fasa ke tanah dan pelepasan beban secara tiba - tiba, selanjutnya dapat dibuatkan tabel data sebagai berikut: 
Jurnal Qua Teknika, Vol. 8 No. 2 September 2018

p-ISSN: 2088-2424; e-ISSN: 2527-3892

Fakultas Teknik Universitas Islam Balitar, Blitar

Http://qua.unisbablitar.ejournal.web.id; Email; quateknika@Gmail.com

Mustofa ihwanudin, Yanu Shalahuddin, Fajar Yumono. 2018. Simulasi Gangguan Voltage Sag dan

Voltage Swell Pada Jaringan 20 kv Menggunakan Matlab Simulink.

Jurnal Qua Teknika, (2018), 8(2) : 1-15

Tabel 2. Data hasil simulasi

\begin{tabular}{|c|c|c|c|c|c|c|c|c|}
\hline \multirow{3}{*}{ No } & \multirow{3}{*}{ Nama tipe gangguan } & \multirow{3}{*}{ Beban } & \multirow{2}{*}{\multicolumn{3}{|c|}{$\begin{array}{l}\text { Besar penurunan dan } \\
\text { kenaikan tegangan } \\
\text { Phasa (pu) }\end{array}$}} & \multirow{2}{*}{\multicolumn{2}{|c|}{$\begin{array}{c}\text { Durasi waktu } \\
\text { (a) }\end{array}$}} & \multirow{3}{*}{$\begin{array}{l}\text { Golongan } \\
\text { gangguan }\end{array}$} \\
\hline & & & & & & & & \\
\hline & & & a & $\mathrm{b}$ & c & Mulai & Selesai & \\
\hline \multirow{3}{*}{1} & \multirow{3}{*}{ Phasa - tanah ( $\mathrm{Yg} / \mathrm{Yg})$} & 1 & $-0,43$ & 0 & $-0,42$ & 0.1 & 0.2 & $\begin{array}{c}\text { Voltage } \\
\text { Sag }\end{array}$ \\
\hline & & 2 & 0 & 0 & $-0,02$ & 0.1 & 0.2 & Normal \\
\hline & & 3 & 0 & 0 & $-0,02$ & 0.1 & 0.2 & Normal \\
\hline \multirow{3}{*}{2} & \multirow{3}{*}{ Phasa - tanah ( $\Delta / \mathrm{rg})$} & 1 & $-0,42$ & 0 & $-0,42$ & 0.1 & 0.2 & $\begin{array}{c}\text { Voltage } \\
\text { Sag }\end{array}$ \\
\hline & & 2 & 0 & 0 & $-0,02$ & 0.1 & 0.2 & Normal \\
\hline & & 3 & 0 & 0 & $-0,02$ & 0.1 & 0.2 & Normal \\
\hline \multirow{3}{*}{3} & \multirow{3}{*}{$\begin{array}{c}\text { Dus phasa - tanah } \\
(\Delta / \mathrm{g})\end{array}$} & 1 & -1 & $-0,46$ & $-0,45$ & 0.1 & 0.2 & $\begin{array}{c}\text { Voltage } \\
\text { Sag }\end{array}$ \\
\hline & & 2 & $-0,01$ & 0 & $-0,02$ & 0.1 & 0.2 & Normal \\
\hline & & 3 & $-0,01$ & 0 & $-0,02$ & 0.1 & 0.2 & Normal \\
\hline \multirow{3}{*}{4} & \multirow{3}{*}{$\begin{array}{c}\text { Dua Phasa - tanah } \\
\text { (Yg/rg) }\end{array}$} & 1 & -1 & $-0,36$ & $-0,36$ & 0.1 & 0.2 & $\begin{array}{c}\text { Voltage } \\
\text { Sag }\end{array}$ \\
\hline & & 2 & $-0,02$ & 0 & $-0,02$ & 0.1 & 0.2 & Normal \\
\hline & & 3 & $-0,02$ & 0 & $-0,02$ & 0.1 & 0.2 & Normal \\
\hline \multirow{3}{*}{5} & \multirow{3}{*}{$\begin{array}{c}\text { Dua phasa - tanah } \\
(\Delta / \Delta)\end{array}$} & 1 & -1 & $-0,44$ & $-0,44$ & 0.1 & 0.2 & $\begin{array}{c}\text { Voltage } \\
\text { Sag }\end{array}$ \\
\hline & & 2 & $-0,02$ & 0 & $-0,02$ & 0.1 & 0.2 & Normal \\
\hline & & 3 & $-0,02$ & 0 & $-0,02$ & 0.1 & 0.2 & Normal \\
\hline \multirow{3}{*}{6} & \multirow{3}{*}{$\begin{array}{c}\text { Tiga Phasa - tanah } \\
(\Delta / g)\end{array}$} & 1 & -1 & -1 & -1 & 0.1 & 0.2 & Interryx \\
\hline & & 2 & $-0,02$ & $-0,02$ & $-0,02$ & 0.1 & 0.2 & Normal \\
\hline & & 3 & $-0,02$ & $-0,02$ & $-0,02$ & 0.1 & 0.2 & Normal \\
\hline \multirow{3}{*}{7} & \multirow{3}{*}{$\begin{array}{c}\text { Pelepasan Beban } \\
\text { C(Yg/rg) }\end{array}$} & 1 & 0,03 & 0,03 & 0,03 & 0.075 & 0.175 & Normal \\
\hline & & 2 & 0,03 & 0,03 & 0,03 & 0.075 & 0.175 & Normal \\
\hline & & 3 & 0,64 & 0,64 & 0,64 & 0.075 & 0.175 & $\begin{array}{l}\text { Voltage } \\
\text { Swell }\end{array}$ \\
\hline \multirow{3}{*}{8} & \multirow{3}{*}{$\begin{array}{c}\text { Pelepasan Beban C } \\
(\Delta / \text { g })\end{array}$} & 1 & 0,03 & 0,03 & 0,03 & 0.075 & 0.175 & Normal \\
\hline & & 2 & 0,03 & 0,03 & 0,03 & 0.075 & 0.175 & Normal \\
\hline & & 3 & 0,62 & 0,62 & 0,62 & 0.075 & 0.175 & $\begin{array}{l}\text { Voltage } \\
\text { Swell }\end{array}$ \\
\hline
\end{tabular}

Berdasarkan tabel diatas pada hubung singkat satu fasa ke tanah perbedaan sambungan transformator tidak mempengaruhi besarnya voltage sag. Pada hubung singkat dua fasa ke tanah sambungan transformator $\mathrm{Yg} / \mathrm{Yg}$ mempunyai hasil yang berbeda dibandingkan dengan sambungan tranformator $\Delta / \mathrm{Vg}$ atau $\Delta / \Delta$. Perbedaan itu sebesar $0.1 \mathrm{pu}$. Dimana voltage sag yang terjadi pada fasa a dan c sebesar $0.36 \mathrm{pu}$, sedangkan sambungan transformator $\Delta / \mathrm{Yg}$ dan $\Delta / \Delta$ menyebabkan voltage sag fasa b dan c sebesar $0,46 \mathrm{pu}$. Gangguan tiga fasa ke tanah menyebabkan interrup pada ketiga fasa.Pelepasan beban pada bus $\mathrm{C}$ dengan sambungan transformator $\mathrm{Yg} / \mathrm{Yg}$ dan $\Delta /$ yg tidak memunjukkan perbedaan sinyal voltage swell. Dimana sambungan transformator Yg/Yg sebesar 0,64 pu sedangkan sambungan transforamtor $\Delta / \mathrm{Yg}$ sebesar $0,63 \mathrm{pu}$.

\section{SIMPULAN}

Hasil simulasi gangguan voltage sag dan voltage swell jaringan distribusi $20 \mathrm{kv}$ menggunakan matlab simulink, dapat diambil kesimpulan sebagai berikut :

a) Pemodelan simulasi mampu menggambarkan terjadinya gangguan voltage sag dan voltage swell

b) Pada gangguan hubung singkat phasa ke tanah dengan perbedaan sambungan trafo $\Delta / \mathrm{\vee g}, \Delta / \Delta, \vee \mathrm{g} / \mathrm{Vg}$,

tidak menunjukan adanya perbedaan besarnya voltage sag 
Jurnal Qua Teknika, Vol. 8 No. 2 September 2018

p-ISSN: 2088-2424; e-ISSN: 2527-3892

Fakultas Teknik Universitas Islam Balitar, Blitar

Http://qua.unisbablitar.ejournal.web.id; Email; quateknika@Gmail.com

Mustofa ihwanudin, Yanu Shalahuddin, Fajar Yumono. 2018. Simulasi Gangguan Voltage Sag dan

Voltage Swell Pada Jaringan 20 kv Menggunakan Matlab Simulink. Jurnal Qua Teknika, (2018), 8(2) : 1-15

c) Pelepasan beban pada bus $\mathrm{C}$ dengan perbedaan sambungan transformator $\mathrm{Yg} / \mathrm{Yg}$ dan $\Delta / \mathrm{Vg}$ tidak menunjukkan adanya perbedaan besarnya voltage swell

\section{REFERENSI.}

[1] Shalahuddin, Yanu. 2015.Mitigasi voltage sag dengan dynamic voltage restore berbasis presag menggunakan matlab/simulink. Semarang : Mte unissula.

[2] Sedaghati, Reza dkk. 2013. A survey of voltage sags and swells phenomena in power quality problems. IJSRM :Vol.1.Issue 9.Pages. 458-462

[3] Wiharya,Candra dkk,. 2014.Analisis Voltage Sag pada Sistem Tenaga Listrik PT. Petrochina International Ltd. Sorong. Jurnal EECCIS.vol.1.no.1

[4] Sinegar, Ronaldi Tumpal dkk,.2014. Analisis dan Proteksi Voltage Sag and Swell akibat Pengoperasian Motor dengan Kapasitas diatas 5000 KW pada sistem kelistrikan P.T Semen Gresik Pabrik Tuban IV. Surabaya : Kampus ITS Keputih Sukolilo

[5] Saputra, Agung Ahmad Sulton. 2017. kompensasi tegangan drop pada penyulang PT. PLN(PERSERO) Distribusi LAMPUNG dengan penempatan DVR. Bandar Lampung : Jurnal Teknik Elektro ITP, Volume 1, No. 2

[6] Sinha, Manish N. \& Dr.B.R.Parekh. 2014. Simulation of Voltage Sag Magnitude Estimation in a Power System Network.vol 3. Issue. ISSN (Print) : 2320 - 3765

[7] Dugan, R. C.; \& Mc Granaghan, M. F.; \& Santoso, S.; \& Beaty, H. W. Electrical Power System Quality $2^{\text {nd }}$ Edition. New York: Mc Graw Hill.

[8] Pawar, N. B.; \& Kakre, D. M. 2014. Generation of Different Types of Voltage Sag Using Matlab/Simulink. IJEIT. Vol. 3. Issue 9. ISSN 2277-3754.

[9] Mali, Vima P., dkk. 2015. A Technical Investigation of Voltage Sag. American Journal of Engineering Research (AJER) : e-ISSN; 2320-0847, p-ISSN ; 2320-0936 Volume-4, Issue10.

[10] Tarto, Deinala Dwi. 2017. Analisa total harminik distrortion menggunakan matlab simulink di universitas islam kadiri. Kediri: Teknik elektro.

[11] Sujatmiko, Hernawan. 2009. Analisis kerugian daya pada saluran transmisi tegangan ekstra tinggi $500 \mathrm{kv}$ di p.t. Pln (persero) penyaluran \& pusat pengaturan beban (p3b) jawa bali regional jawa tengah \& diy unit pelayanan transmisi semarang. Jurnal Teknik Elektro : Vol. 1 No. 1

[12] Anton, D.; \& Rosyadi, I.; \& Ashari, M.; \& Suryoatmojo, H. 2009. Kombinasi Feed Back dan Feed Forward Kontroller PI sebagai Kendali Dynamic Voltage Restorer (DVR) untuk memulihkan Voltage Sag dan Interruption. Telkomnika, Volume 7, nomor 2. ISSN 16936930.

[13] Badaruddin \& Heri kiswanto. 2015. Studi analisa perencanaan instalasi distribusi saluran udara tegangan menengah (sutm) $20 \mathrm{kv}$. Jakarta : Universitas Mercu Buana vol 6, No. 01

[14] ramono, Joko, dkk. 2010. “makalah transmision of elektrical energy”. Depok : Depertemen eknik elektro UI

[15] “IEEE Recommended Practice for Monitoring Electric Power Quality,” IEEE Std. 11591995, June 1995. 